\title{
Development and Characterization of Nano-Particle Embedded Soy Protein Isolate Films
}

\author{
Rakesh B. Gautam ${ }^{1}$ and Satish Kumar ${ }^{2}$
}

${ }^{1 \& 2}$ Dept. of Processing and Food Engineering, PAU, Ludhiana (141 004), India

\section{Article History}

Manuscript No. AR1560

Received in $15^{\text {th }}$ November, 2015

Received in revised form $27^{\text {th }}$ March, 2016

Accepted in final form $4^{\text {th }}$ April, 2016

\section{Correspondence to}

"E-mail: rksh_gautam@yahoo.co.in

\section{Keywords}

Bio-degradable films, soy protein isolate, $\mathrm{TiO}_{2}$

\begin{abstract}
Most of the Food packaging is non-degradable, which is responsible for environmental pollution. Different types of biopolymers have been exploited to develop materials for eco-friendly food packaging. However, the use of biopolymers has been limited because of their usually poor mechanical and barrier properties, which may be improved by adding reinforcing compounds (fillers), strengthen materials present poor matrix-filler interactions, which tend to improve with decreasing incorporating materialsize. The naturally renewable biopolymers have attracted much attention because of the high potential use as edible and biodegradable films for food packaging. Biodegradable-soy protein isolate-glycerol-Titanium dioxide $\left(\mathrm{TiO}_{2}\right)$ blend films were developed and characterized as a function of different sonication levels $(0,2040,60$, 80 and $100 \%$ ). Results showed that the water vapour permeability, moisture content, moisture absorption and water solubility decreased with increasing sonication level. Mechanical tests revealed the plasticizing effect of nano-particles on the bio-film. At higher $\mathrm{pH}$ level improves barrier properties as well as mechanical properties. Increasing $\mathrm{pH}$ level from 8-10 the elongation at break and barrier properties showed good results. The final films had an opaque appearance because of presenting titanium di-oxide as strengthen material in developed biopolymeric film. Physical properties (viz., Area, thickness of film) of soy protein showed improved with increasing sonication levels as well as $\mathrm{pH}$ values. Application of sonication to soy protein isolate films solution significantly increased tensile strength and its elongation at break.
\end{abstract}

\section{Introduction}

In Indian contest it is very important to take care of environment pollution because a huge population. So a large amount of packaging material is required to fulfil the need and this is available as undegradable which is harmful to environment and human beings also. New bio-based materials have been exploited to develop edible and biodegradable films as a big effort to extend shelf life and improve quality of food while reducing packaging waste (Tharanathan, 2003). The use of edible and biodegradable polymers has been limited because of problems related to performance (such as brittleness, poor gas and moisture barrier), processing (such as low heat distortion temperature), and cost. Starch, as an example, has received considerable attention as a biodegradable thermoplastic polymer. It had a poor performance by itself because of its water sensitivity and limited mechanical properties (Vaidya and Bhattacharya, 1994) with high brittleness, which was related to the anarchical growth of amylose crystals with time (Dufresne and Vignon, 1998). The application of nanotechnology to these polymers may open new possibilities for improving not only the properties but also the cost-price-efficiency (Sorrentino, Gorrasi and Vittoria, 2007).

Development of a new source of packaging materials to replace non-biodegradable petroleum-based plastic materials has recently received increasing attention since synthetic plastic materials have led to serious environmental concerns as a result of their non-biodegradability and depletion of natural resources. In addition, the increasingly high oil prices are another driving force for the development of substitutes for synthetic plastics. Biopolymers such as polysaccharides, proteins, lipids and their blends are considered the most promising candidates for this purpose because of their biodegradability, sustainability, and abundance.

Soy protein had been regarded as a viable alternative to the petroleum polymers in the manufacture of adhesives, plastics, and packaging materials (Lu et al., 2004; Mohanty et al., 2005; Liu et al., 2010). Soy protein observed the major co-product of soybean oil and was readily available and renewable. The 
commercial raw material of soy protein was soy protein isolate (SPI) with more than $90 \%$ protein and 18 diverse amino acids. Usually, the poor mechanical performance as well as the water sensitivity of soy protein materials which limit their applications (Tian et al., 2009), could be improved, such as by blending with polyurethane (Tian et al., 2010a), gelatin (Cao et al., 2007), natural rubber (Tian et al., 2010b), cellulose derivates (Su et al., 2010), chitosan (Silva et al., 2007), konjac glucomannan (Tang et al., 2003), lipid (Monedero et al., 2010) and beeswax (Monedero et al., 2009), filling with nanoparticles (Kumar et al., 2010; Liu et al., 2009) or chemical modifications (Kumar, 2010). Antimicrobial packaging was one of active packaging system which was achieved by adding active chemicals in the packaging system (Han, 2003), and it can inhibit or reduce the growth rate of microorganisms in the foods.

Soy protein blend films prepared by solution casting possessed an enhanced tensile strength compared with those thermo-moulding films. The casting films also exhibited high stretchability with a high elongation at break. The better mechanical properties of casting SPI film could be due to the formation of the compact and homogeneous three-dimensional structure nano-particle.

The success of biopolymer packaging films in meeting the barrier needs of a food product was strongly influenced by many factors, including the nature and composition of the film and the environmental conditions. For instance, highly polar polymers, such as starch-and protein-based films, generally exhibit high water vapour permeability (WVP) but low gas permeability. On the other hand, non-polar polymers, such as lipids, tend to show reverse effects (McHugh and Krochta, 1994a; McHugh and Krochta, 1994b). Humidity and temperature of the environment also affect the barrier properties of biopolymer films. Moisture and oxygen permeability may increase with increasing relative humidity (Fang et al., 2002) and increasing temperature (Gennadios et al., 1993a; Gennadios et al., 1993b). Therefore, it was necessary to optimize the barrier properties of the biopolymeric materials used as packaging depending on the characteristics and storage conditions of the packaged products.

\section{Materials and Methods}

\subsection{Experimental design and data analysis}

Statistical package Design-Expert Version 7.0 (Statease Inc., Minneapolis, MN, USA) was used to design the experiment. The central composite design CCRD for three independent variables was performed. The independent variables considered were pH (A) Sonication levels (B).

The levels of each variable were established based on the results of earlier experiments and preliminary trials. A rotatable, central composite design (Myers, 1971) was employed to determine the film formation conditions. Experiments were randomized in order to minimize the systematic bias in observed responses due to extraneous factors. The outline of experimental design with the actual level is presented Table 4. Dependent variables were specific film thickness, area of film, moisture content, moisture absorption and viscosity of film forming solution. Response surface methodology was applied for experimental data, for generation of contour plots and for statistical analysis of experimental data. The results were analysed by a multiple regression method which describes the effects of variables in the models derived. Experimental data were fitted to the selected models and regression coefficients were obtained. The analysis of variance (ANOVA) tables were generated for each of the response functions. The effect of each variable and also the effects of interaction term in coded levels of variables were determined.

\subsection{Procurement of materials}

For the present study, Soy protein isolate procured from Natures Valvet Lifecare, Hyderabad, India. Glycerol $\left(\mathrm{C}_{3} \mathrm{H}_{8} \mathrm{O}_{3}\right)$ molecular weight 92.10 , was procured from Awantor performance material Ltd (formely know as RFCL limited), Faridabad Haryana (India). It was colourless and viscous material. Titanium dioxide was an inert, non-toxic and inexpensive nano-particle material with potential activity against a wide variety of microbes due to its pololytic activity. When $\mathrm{TiO}_{2}$ was incorporated into a polymer matrix of a packaging material, it provided protection from food borne microorganism as well as odour $\backslash$ staining $\backslash$ deterioration and allergens due to presence of radiation of relative low wavelength near the ultraviolet region. $\mathrm{The}^{\mathrm{TiO}}{ }_{2}$ film exhibits excellent mechanical and chemical durability in the visible and near infrared region (Zhou et al., 2009). Incorporation of $\mathrm{TiO}_{2}$ into synthetic plastic matrix to increase the bio-degradability has been investigated by Kadam et al. (2013). For the present study, $\mathrm{TiO}_{2}$ nano-particle (m.w. 79.90) was procured from Awantor Performance Material Ltd (formely know as RFCL limited), Faridabad, Haryana (India).

\subsection{Procedure for development of bio-film}

The SPI films were prepared using fixed level of $\mathrm{TiO}_{2}(5 \%) \mathrm{SPI}$ (5\%) and glycerol contents, (1.5\%). The control film solution was prepared by dissolving $5 \mathrm{~g}$ of WPI in $100 \mathrm{ml}$ distilled water with $1.5 \mathrm{~g}$ of glycerol. In the preparation of SPI film solutions, $\mathrm{TiO}_{2}$ was first dispersed into distilled water $(100 \mathrm{ml})$ and stirred using a magnetic stirrer overnight to reach complete hydration/swelling. Subsequently $5 \mathrm{~g}$ of WPI was added to 
obtain an aqueous solution, followed by addition of $1.5 \mathrm{~g}$ of glycerol. The film solutions were heated at $90^{\circ} \mathrm{C}$ for $15 \mathrm{~min}$ in a water bath, cooled to room temperature and degassed using a bath-type ultrasound sonicator (Sonica, ultrasonic cleaner, $2200 \mathrm{MH}$, Spincotech Pvt Ltd). The film forming solutions were then spread onto levelled Teflon-coated sheet $(24 \times 30$ $\mathrm{cm})$. The cast films were dried at an ambient temperature $\left(20-25{ }^{\circ} \mathrm{C}, 50 \pm 5 \% \mathrm{RH}\right)$ for 2 days and then peeled off from surface and stored for further analysis.

\subsection{Determination of film characteristics}

\subsubsection{Film solution parameters}

Temperatures of the solution were recorded by mercury thermometer after sonication process and just before spreading the solution on Teflon-coated glass plates. Electronic balance (FX400 FCOSET) was used to measure weight of film solution as well as films so formed. Its least count was found to be $0.001 \mathrm{~g}$.

\subsubsection{Viscosity of solution}

Viscosity of SPI based film was determined by using Bohlin 100 Rheometer. Two $\mathrm{ml}$ of sample was placed between the plates and the gap between the plates was adjusted to $100 \mu \mathrm{m}$. The viscosity of the solution was obtained at the temperature $30{ }^{\circ} \mathrm{C}$. For viscosity determination shear rate of $371 \mathrm{~s}^{-1}$ was taken (Dimante and Lan, 2014).

\subsubsection{Thickness and area of film}

Thickness of the developed packaging film was measured with the help of digital micrometer (Model: IP-65, Mitutoya Corp., Tokyo, Japan) with sentivity of $\pm 0.001 \mathrm{~mm}$ (Kadam et al., 2013). The measurements of thickness were carried out on different location each of film and average values were determined (Cao et al., 2007). After drying of film the length and width were measured by scale and area was determined.

\subsubsection{Moisture content}

The moisture content (MC) of films so formed was determined by measuring the weight of films before and after drying in a laboratory oven (Shimaz, Iran) at $105 \pm 1{ }^{\circ} \mathrm{C}$. The film was dried until constant weight was reached. The observations were replicated thrice

$\mathrm{MC}=\{(\mathrm{Wi}-\mathrm{Wf}) / \mathrm{Wi}\} \times 100$

Where $\mathrm{Wi}=$ initial weight of film, Wf=final weight of film

\subsubsection{Moisture absorption}

Moisture absorption (MA) was measured according to the modified method (Almasi et al., 2010). The dried sheets of $20 \times 20 \mathrm{~mm}$ were first conditioned at $0 \% \mathrm{RH}$ (calcium sulphate) for $24 \mathrm{~h}$. After weighing, they were conditioned in a desiccators containing calcium nitrite saturated solution at $25^{\circ} \mathrm{C}$ to ensure a RH of $55 \%$. The samples were weighed at desired intervals until the equilibrium state was reached. The MA of the samples was calculated by using the relationship

$\mathrm{MA}=\left(\mathrm{W}_{\mathrm{t}}-\mathrm{W}_{0}\right) / \mathrm{W}_{0}$

Where, $\mathrm{W}_{\mathrm{t}}=$ weight of treated film, $\mathrm{W}_{0}=$ initial weight of film

\section{4.6. Bio-degradability of films}

Fifteen samples of each film were placed in a box, buried in soil having $25 \% \mathrm{mc}$. The box was placed in desiccators where the $75 \%$ relative humidity and $25{ }^{\circ} \mathrm{C}$ temperature were adjusted. The samples were taken out at 10 days interval and weighed.

\section{4.7. Mechanical characteristics}

Texture analyser TA_XT (Stable Micro System) with 50 $\mathrm{N}$ load cell equipped with tensile grip was used to measure the tensile strength of different packaging films according to ASTM D-882 standard. Grip separation was set at $50 \mathrm{~mm}$, with a crossed head speed of $5.0 \mathrm{~m} \mathrm{~s}^{-1}$. The TS and elongation at break (\%) were calculated by using relationship

$\mathrm{TS}=\mathrm{F} / \mathrm{L} \times \mathrm{W}$

Where; TS tensile strength (MPa), F: Tension at break, L and W represents the length $(\mathrm{mm})$ and with width $(\mathrm{mm})$ of film sample respectively (Quing et al., 2009)

$\mathrm{E}_{\mathrm{b}}(\%)=\mathrm{l}_{\mathrm{b}} / 1_{\mathrm{o}} \times 100$

Where, $\mathrm{E}_{\mathrm{b}}$ represents the Elongation at break (\%) $\mathrm{l}_{\mathrm{b}}$ : measured elongation at break $(\mathrm{mm})$ and $1_{\mathrm{o}}$ is Original specimen length (mm)

\subsubsection{Water vapour permeability}

Water vapour permeability (WVP) is a proportional constant assumed to be independent of the water vapour pressure gradient applied across the film. WVP was determined using Gravimetric method as per ASTM E 96 using aluminium cups (Kadam et al., 2013). About $50 \mathrm{~cm}^{2}$ dia sample were sealed on the aluminium cups containing highly hygroscopic fused $\mathrm{CaCl}_{2}$. Samples surface areas of film was sealed using hot wax. Before placing the samples in the humidity chamber, samples were kept at room temperature and weight was noted down. The sealed cups were kept in chamber at a temperature $38 \pm 1{ }^{\circ} \mathrm{C}$ at $90 \% \mathrm{RH}$. The samples were checked for gain in weight at periodic intervals. The gain in weight was due to the absorption of moisture by $\mathrm{CaCl}_{2}$ which permeated through the film. Weight gain was plotted against time and linear least-square method was used to calculate WVTR using the following formula:

Water vapour transmission rate $($ WVTR $)=$ Slope $\times$ area of sample $\left(\mathrm{gm} \mathrm{m}^{-2}\right.$ day $\left.^{-1}\right)$

\subsubsection{Gas transmission rate}

The packaging film samples were cut in to circular shape using the templates supplied with permeability cell. Oxygen 
transmission rate (OTR) of the films was determined according to ASTM-D 1484 standard using permeability cell (Model CS-135; C, Custom Scientific Instruments). The instrument consisted of two stainless steel disc having permeability cell which formed cylindrical cavity when disc are superimposed. The samples to be tested for OTR were placed between the disc using six equally spaced bolts after placing filter as support on the upper disk and a rubber gasket to fit the pressure tightly. The cell consisted of a glass capillary in a vertical position to an opening in the centre of the upper disc. Suitable gas inlet and vent lines were provided on both sides of the cells. Oxygen was supplied from a cylinder at a constant pressure to the bottom inlet of the cell. A short plug of mercury, contained in the capillary, was displaced upward by the permeating gas through the packaging material. An electro-mechanical vibration was used to avoid friction to the movement of plug. The change in the volume of permeater was measured as a function of time.

\subsubsection{Optical characteristics}

Hunter colorimeter (Color Reader Model CR-10) was used for the measurement of color (Optical properties) of the developed packaging film (Cho et al., 2010). The color was measured using CIELAB scale at $10^{9}$ at $\mathrm{D}_{65}$ illuminant. It works on the principle of focussing the light and measured energy reflected from the sample across the entire visible spectrum. The three dimensional scale $\mathrm{L}^{*}, \mathrm{a}^{*} \mathrm{~b}^{*}$ was used. $\mathrm{L}^{*}$ is the lightness coefficient, ranging from 0 (black) to 100 (white), $\mathrm{a}^{*}$ represents greenness (-ve) and redness $(+)$. While $b^{*}$ represents yellowness (+ve) and blueness (-ve), C represents Chroma $\mathrm{H}$ represents Hue angle. The instrument was calibrated by placing black tile and white tile provided with the instruments. Once the instrument was calibrated, it was ready to measure the color parameters. The sample was placed in the sample cup. The deviation of the color of the sample to standard was also observed and recorded in the computer interface. The measurements were replicated thrice. $\Delta \mathrm{E}, \mathrm{C}$ and $\mathrm{H}$ were determined using the following relationship.

$\Delta \mathrm{E}=\sqrt{ }\left(\Delta \mathrm{L}^{2}+\Delta \mathrm{a}^{2}+\Delta \mathrm{b}^{2}\right)$

Where $\Delta \mathrm{E}=$ Color change, $\Delta \mathrm{L}=\mathrm{L}$ control film $-\mathrm{L}$ treated film $\Delta \mathrm{a}=\mathrm{a}^{*}$ control film-a treated film, $\Delta \mathrm{b}=\mathrm{b}^{*}$ control film- $\mathrm{b}^{*}$ treated film.

$C=\sqrt{ } a^{* 2}+b^{* 2}$

$\mathrm{H}=\tan ^{-1}\left(\mathrm{~b}^{*} / \mathrm{a}^{*}\right)$

Where $\mathrm{H}$ is denoted hue angle and $\mathrm{C}$ denoted as chroma

\subsubsection{Thermal characteristics}

Thermal properties of the composite films were measured using differential scanning calorimetry (DSC) equipment (Mettler Toledo, DSC1 Star System). A $10 \mathrm{mg}$ film sample was cut into small pieces and placed into a sample pan of DSC equipment. An empty aluminium pan as reference was used. Samples were scanned at a heating rate of $1{ }^{\circ} \mathrm{C} \mathrm{min}^{-1}$ between temperatures ranging from 0 to $250{ }^{\circ} \mathrm{C}$. The nitrogen gas was used as the purge gas at a flow rate of $20 \mathrm{ml} \mathrm{min}^{-1}$. The melting point (Tm) was calculated as the temperature where the peak of the endotherm occurs. The Tm of the each film was determined in triplicate and the results were averaged.

\subsubsection{Statistical analysis}

Design Expert 7.0 was used for optimization of process parameters and prediction of optimised values of responses. The results obtained from all experiments were subjected to analysis of variance (ANOVA), applying a completely randomized design, using SPSS 13 software (Version 22.0; SPSS Inc., Chicago, USA). Duncan's multiple ranges test were used to compare the difference among mean values of film specimens' properties at the level of (0.05).

\section{Results and Discussion}

\subsection{Film characteristics}

\subsubsection{Film formation parameters}

Average temperature of solution was found at $65{ }^{\circ} \mathrm{C}$ at the time of sonication. Weight of film was recorded in range from 11.925 to $16.881 \mathrm{~g}$ while weight of control film was $17.000 \mathrm{~g}$. Weight of film was varied due to moisture retained into films. Moisture retention significantly decreased with increasing the $\mathrm{pH}$ as well as sonication levels $(p<0.05)$.

\subsubsection{Viscosity of solution}

Viscosity of film forming solution was found 24.251 (control) to $36.925 \mathrm{mPas}$. Viscosity of film forming solution was significantly increased when increasing the sonication levels $(p<0.05)$. A significant effect of $\mathrm{pH}$ also found. Viscosity was found slightly increased with increasing $\mathrm{pH}$ values.

\subsubsection{Thickness of the film}

Film thickness was found 0.030 to $0.046 \mathrm{~mm}$. Film thickness was recorded decreased with increasing $\mathrm{pH}$ values due to increasing cross linking activity at high ph levels (Brandenburg et al., 1993). By increasing the sonication levels the film thickness resulted in decreasing trend with good elongation and tensile strength $(p<0.05)$.

\subsubsection{Moisture absorption and moisture content}

It was one of the most important problems in the use of biopolymer materials is its MA tendency, and any improvement in water resistance is thus very important (Tang et al., 2008). The MA value of the control film was $16.98 \pm 0.85 \%$, while the sonicated film had the lowest MA at about $5.85 \pm 0.16 \%$. When sonication levels was varied from 20 to 100 , MA values of the films increased, but it was still much lower than that of the blend film. The results can be explained as 
the low hydrophilicity of $\mathrm{TiO}_{2}$ nanoparticles compared with SPI suggesting the network structure formed by combining nano- $\mathrm{TiO}_{2}$ with SPI could prevent the water molecules from dissolving and thus, improves the water resistance of the film. WS value is an important functional property for the film made based on biopolymers, which is related to the hydrophilicity of the materials (Ghasemlou et al., 2011). Also, MC value is a parameter related to the total void volume occupied by water molecules in the network microstructure of the film $(\mathrm{Li}$ et al., 2011). As shown in Table 1, MC values of blend films containing $\mathrm{TiO}_{2}$ nanoparticles were less than that of SPI film. These results indicate that the addition of nano- $\mathrm{TiO}_{2}$ to SPI solution decreased the $\mathrm{MC}$ of biocomposite films compared to WPI film. The mean MC value decreased from 33.52 to $18.65 \%$, with giving the sonication treatment by increasing the $\mathrm{pH}$ levels to 10 the $\mathrm{MC}$ value decreasing to $18.65 \%$. The WS of the blend film generally decreased with an increase in $\mathrm{pH}$ values and sonication levels $(p<0.05)$.

The thickness of film was found descreased with increasing sonication level as well as $\mathrm{pH}$ levels. A significant increament in of area of film was observed. Weight of film was obeserved decreasedwith increasing $\mathrm{pH}$ and sonication levels. Soy protein isolate is partially insoluble at low $\mathrm{pH}$ which leads to limited cross-linking and film structres development (Brandenburg et al., 1993). The polymer which is developed on the basis of nano-technology concept. Improve the physical properties; strength and biodegradability of film incorporate the $\mathrm{TiO}_{2}$ nanopowder.

\subsection{Optical characteristics}

The optical properties of the SPI and SPI/TiO ${ }_{2}$ composite

sonicated films, determined by CIE colour values, are shown in Table 2. In general, the optical properties of the WPI films were significantly $(p<0.05)$ influenced by giving sonication as well as $\mathrm{pH}$ treatment with the nano- $\mathrm{TiO}_{2}$. Showed the lowest $\mathrm{L}^{*}$ and $a^{*}$ values but highest $b^{*}$ and $\Delta E$ values. This may be attributed to the high surface hydrophobicity of $\mathrm{TiO}_{2}$ embedded film (Park et al., 2002), which could hinder complete dispersion into a hydrophilic SPI film solution. Generally, intercalation between biopolymers and nano-clays is known to depend on the compatibility and the surface polarities of both components (Park et al., 2002).

\begin{tabular}{lcccc}
\hline \multicolumn{5}{l}{ Table 2: Optical properties of film } \\
$\mathrm{pH}$ levels & Sonication levels & $\mathrm{L}^{*}$ & $\mathrm{a}^{*}$ & $\mathrm{~b}^{*}$ \\
\hline Control & 0 & 91.2 & -3.5 & 5.0 \\
8.5 & 60 & 88.4 & -2.7 & 7.8 \\
7.0 & 20 & 92.2 & -3.7 & 5.8 \\
10.0 & 20 & 91.2 & -3.9 & 8.7 \\
7.0 & 100 & 84.6 & -2.5 & 9.0 \\
8.5 & 60 & 85.6 & -3.7 & 8.5 \\
8.5 & 60 & 86.6 & -5.7 & 6.8 \\
8.5 & 116.57 & 78.9 & -3.6 & 11.8 \\
8.5 & 60 & 80.6 & -6.6 & 11.8 \\
8.5 & 3.43 & 91.5 & -3.4 & 11.0 \\
10.62 & 60 & 80.9 & -2.5 & 10.0 \\
10.00 & 100 & 74.8 & -3.7 & 9.8 \\
6.38 & 60 & 89.6 & -6.7 & 9.7 \\
8.5 & 60 & 78.6 & -5.9 & 11.0 \\
\hline
\end{tabular}

\begin{tabular}{lccccccc}
\hline \multicolumn{7}{l}{ Table 1: Effect of pH and sonication levels on Physical and chemical properties of developed film } \\
\hline pH levels & $\begin{array}{c}\text { Sonication } \\
\text { levels }(\%)\end{array}$ & $\begin{array}{c}\text { Thickness } \\
(\mathrm{mm})\end{array}$ & $\begin{array}{c}\text { Area of film } \\
\left(\mathrm{cm}^{2}\right)\end{array}$ & $\begin{array}{c}\text { Weight of } \\
\text { film }\end{array}$ & $\begin{array}{c}\text { Moisture } \\
\text { content }(\%)\end{array}$ & $\begin{array}{c}\text { Moisture } \\
\text { absorption }(\%)\end{array}$ & $\begin{array}{c}\text { Viscosity of film } \\
(\mathrm{mPaS})\end{array}$ \\
\hline Control & 0 & 0.046 & 300 & 17.000 & 35.00 & 16.98 & 24.251 \\
8.5 & 60 & 0.041 & 400 & 14.255 & 25.00 & 8.55 & 28.661 \\
7.0 & 20 & 0.056 & 380 & 15.989 & 33.52 & 10.92 & 25.295 \\
10.0 & 20 & 0.06 & 360 & 12.891 & 20.92 & 6.95 & 24.920 \\
7.0 & 100 & 0.036 & 464 & 11.925 & 22.05 & 8.25 & 30.961 \\
8.5 & 60 & 0.041 & 400 & 14.010 & 20.15 & 7.25 & 32.565 \\
8.5 & 60 & 0.041 & 380 & 13.191 & 20.45 & 6.291 & 33.000 \\
8.5 & 116.57 & 0.031 & 484 & 13.025 & 18.00 & 5.11 & 36.925 \\
8.5 & 60 & 0.044 & 420 & 13.565 & 21.92 & 6.62 & 36.191 \\
8.5 & 3.43 & 0.068 & 360 & 16.881 & 23.62 & 7.00 & 25.912 \\
10.62 & 60 & 0.036 & 464 & 13.621 & 20.66 & 6.00 & 32.251 \\
10.00 & 100 & 0.03 & 450 & 12.586 & 18.65 & 5.85 & 37.195 \\
6.38 & 60 & 0.037 & 464 & 15.612 & 21.91 & 12.25 & 34.962 \\
8.5 & 60 & 0.042 & 400 & 11.855 & 20.11 & 6.59 & 35.021 \\
\hline
\end{tabular}




\subsection{Mechanical characteristics}

The mechanical characteristics viz., Tensile strength and Elongation break were obtained by using texture analyser. The tensile properties of the SPI films increased after giving treatment of sonication at different levels (Table 4). The tensile properties of the $\mathrm{TiO}_{2}$ embedded WPI films showed significantly increased $(p<0.05)$, which increased remarkably compared to the control sonication level on $\mathrm{TiO}_{2}$ embedded WPI films.

It was reported to be improved by the formation of the nanocomposite. The increase in the TS and EM of such bionanocomposite films can be attributed to the high rigidity and aspect ratio of the nano-particle as well as the high affinity between biopolymer and nano-particle (Rhim et al., 2006). For present study, the tensile properties of $\mathrm{SPI} / \mathrm{TiO}_{2}$ composite films increased compared to the control SPI films, directly indicating that a nanocomposite was formed between the $\mathrm{TiO}_{2}$ and the polymer matrix, but rather the nano- $\mathrm{TiO}_{2}$ worked as filler for the composite films (Rhim et al., 2008). The moisture barrier properties of SPI films improved as $\mathrm{pH}$ of the filmforming solution was increased.

\subsection{Thermal characteristics}

The mechanical characteristics viz., melting Temperature (Tm) and temperature of glass transition ( $\mathrm{Tg}$ ) were determined by Differential Scanning Calorimeter. DSC studies of the $\mathrm{TiO}_{2}$ embedded WPI films containing fixed contents of glycerol were performed to further understand the structure and interaction between polymer and nano- $\mathrm{TiO}_{2}$ The $\mathrm{Tg}$ temperature is the temperature indicating the relaxation in a polymer where a material changes from an amorphous solid state (glassy state) to a more viscous rubbery state (Ghasemlou et al., 2011). The thermal properties of control film and the $\mathrm{TiO}_{2}$ embedded SPI film listed in Table 4. The Tg of the nanocomposite was shifted to low temperature by increasing the $\mathrm{TiO}_{2}$ nanoparticles content. The Tg peak temperature of control film was$12.50{ }^{\circ} \mathrm{C}$, the endothermic peak of melting (Tm) also decreased from 85.44 (control film) to $78^{\circ} \mathrm{C}$ (SPI-5\% nano- $\mathrm{TiO}_{2}$ film) at $10 \mathrm{pH}$ and sonication level 100. This behavior was due to the regularity disruption of the chain structures in biopolymer matrix and spacing increase between the chains (Nakayama et al., 2007). In the present study, thermograms demonstrate partial miscibility of nano- $\mathrm{TiO}_{2}$ and SPI at the molecular level for any given concentration ratio. No phase separation was observed (separation of $\mathrm{Tg}$ or melting peaks) because the miscibility of nano- $\mathrm{TiO}_{2}$ and SPI remained homogenous during heating cycle. If mixtures of polymer and nano- $\mathrm{TiO}_{2}$ were immiscible, the mixture would exhibit two $\mathrm{Tg}$ and $\mathrm{Tm}$ corresponding to the two pure phases (Ghasemlou et al., 2011)

\subsection{Biodegradability of bio-film}

Titanium dioxide embedded whey protein isolate (WPI) film was taken for test of bio-degradability and found that in 30 days weight loss of film was very slow but after 45 days decreasing in weight was found high. The effect of $\mathrm{TiO}_{2}$ in weight loss was found not significant.

\subsection{Optimum values of process parameters and responses}

The optimum values of process parameters and responses were presented in Table 5. The process conditions for development of film were optimized using numerical optimization techniques. The main criteria for constraints optimization were maximum possible Film thickness, Area of film, weight of film, colour changes, viscosity, moisture and moisture absorbance quality of polymeric film. In order to optimize the process conditions for development of bio-polymeric film by numerical optimization techniques, equal importance of ' 3 ' was given to process parameters (viz., $\mathrm{pH}$ levels and sonication levels) and responses( i.e. film thickness, area of film, weight of film viscosity, moisture content and moisture absorbance quality of the film). The conditions were experimentally verified with deviation of $+0.1 \%$. The optimum conditions for $\mathrm{pH}$ and sonication level were 8.5 and 60 respectively. The overall desirability was 0.955 .

\begin{tabular}{lccccc}
\hline \multicolumn{6}{l}{ Table 3: Mechanical characteristics } \\
\hline $\begin{array}{l}\mathrm{pH} \\
\text { levels }\end{array}$ & $\begin{array}{c}\text { Sonica- } \\
\text { tion } \\
\text { levels }\end{array}$ & $\begin{array}{c}\mathrm{TS} \\
(\mathrm{MPa})\end{array}$ & $\begin{array}{c}\mathrm{EB} \\
(\%)\end{array}$ & $\begin{array}{c}\text { WVTR } \\
(\mathrm{x} 10-11 \\
\left.\mathrm{g} / \mathrm{m}^{2} \mathrm{~s}\right)\end{array}$ & $\begin{array}{c}\text { WVP } \\
(\mathrm{x} 10-11 \mathrm{~g} \\
\left.\mathrm{msPa}^{-1}\right)\end{array}$ \\
\hline 8.5 & 60 & 4.66 & 90.27 & 187.043 & 3.2 \\
7.0 & 20 & 3.72 & 85.2 & 194.391 & 3.88 \\
10.0 & 20 & 4.15 & 100.12 & 163.297 & 2.98 \\
7.0 & 100 & 4.25 & 81 & 154.098 & 2.9 \\
8.5 & 60 & 4.67 & 91.25 & 148.018 & 2.87 \\
8.5 & 60 & 4.59 & 91.25 & 157.233 & 2.69 \\
8.5 & 116.57 & 4.62 & 95.28 & 146.858 & 2.68 \\
8.5 & 60 & 4.61 & 81.12 & 150.803 & 3.01 \\
8.5 & 3.43 & 4 & 84.38 & 208.779 & 3.81 \\
10.62 & 60 & 4.69 & 105.1 & 174.768 & 2.99 \\
10.00 & 100 & 4.8 & 103.25 & 160.125 & 2.89 \\
6.38 & 60 & 3.99 & 84.88 & 151.594 & 2.68 \\
8.5 & 60 & 4.72 & 81.25 & 158.349 & 2.98 \\
\hline
\end{tabular}

\begin{tabular}{lcc}
\hline \multicolumn{3}{l}{ Table 4: Thermal charcterisctics } \\
\hline $\mathrm{pH}$ levels & Sonication levels & $\mathrm{Tm}\left({ }^{\circ} \mathrm{C}\right)$ \\
\hline 7.0 & 0 & 85.44 \\
8.5 & 60 & 70 \\
10 & 100 & 78 \\
\hline
\end{tabular}




\begin{tabular}{|c|c|c|c|c|c|}
\hline $\begin{array}{l}\text { Param- } \\
\text { eters }\end{array}$ & Goal & $\begin{array}{l}\text { Lower } \\
\text { limit }\end{array}$ & $\begin{array}{l}\text { Upper } \\
\text { limit }\end{array}$ & $\begin{array}{l}\text { Impor- } \\
\text { tance }\end{array}$ & $\begin{array}{l}\text { Optimiza- } \\
\text { tion level }\end{array}$ \\
\hline $\begin{array}{l}\text { a. } \mathrm{pH} \\
\text { Level }\end{array}$ & $\begin{array}{l}\text { In } \\
\text { range }\end{array}$ & 7.0 & 10.0 & 3 & 8.5 \\
\hline $\begin{array}{l}\text { b. Sonica- } \\
\text { tion level }\end{array}$ & $\begin{array}{c}\text { In } \\
\text { range }\end{array}$ & 20 & 100 & 3 & 60 \\
\hline $\begin{array}{l}\text { Respons- } \\
\text { es }\end{array}$ & & & & & Prediction \\
\hline $\begin{array}{l}\text { Film } \\
\text { thickness }\end{array}$ & Min & 0.040 & 0.046 & 3 & 0.0418 \\
\hline Area film & Max & 379.29 & 450.73 & 3 & 400 \\
\hline $\begin{array}{l}\text { Weight } \\
\text { film }\end{array}$ & Min & 13.10 & 16.43 & 3 & 13.8005 \\
\hline $\mathrm{L}$ & $\begin{array}{l}\text { In } \\
\text { range }\end{array}$ & 82.92 & 92.24 & 3 & 84.8846 \\
\hline A & In range & -5.16 & -0.60 & 3 & -4.2 \\
\hline B & In range & 8.24 & 13.54 & 3 & 9.36154 \\
\hline $\begin{array}{l}\text { Viscosity } \\
\text { of film } \\
\text { solution }\end{array}$ & Max & 29.97 & 38.82 & 3 & 31.8353 \\
\hline $\begin{array}{l}\text { Moisture } \\
\text { absor- } \\
\text { bance }\end{array}$ & Min & 6.21 & 9.14 & 3 & 7.0602 \\
\hline $\begin{array}{l}\text { Moisture } \\
\text { content } \\
\text { of film }\end{array}$ & Min & 20.27 & 28.84 & 3 & 22.0738 \\
\hline
\end{tabular}

Min: Minimum; Max: Maximum

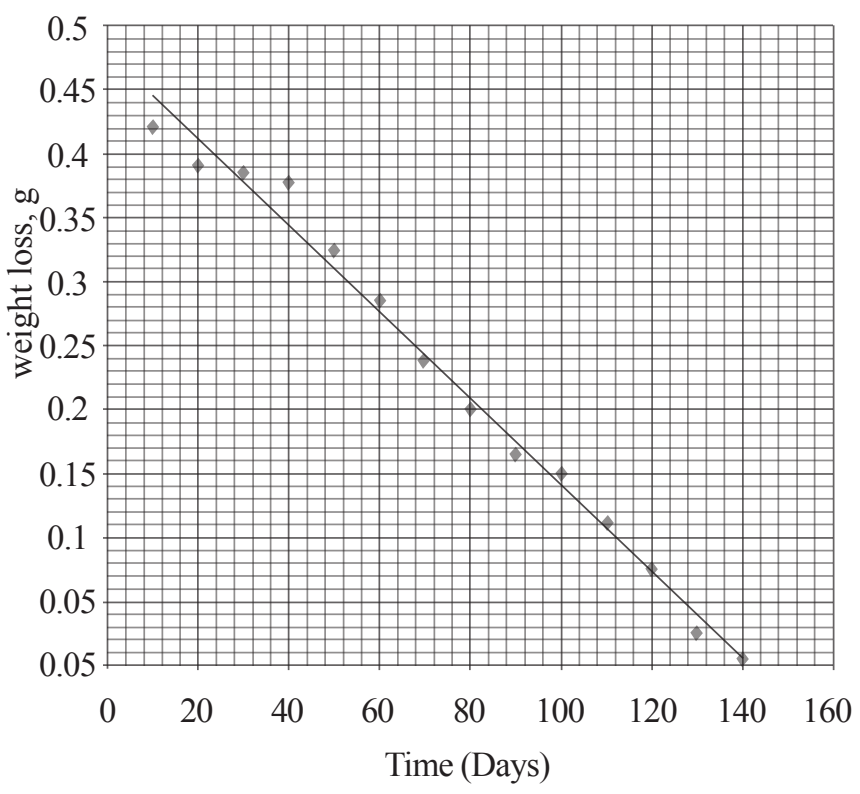

Figure 1: Biodegradability of Soy Protein Isolate film

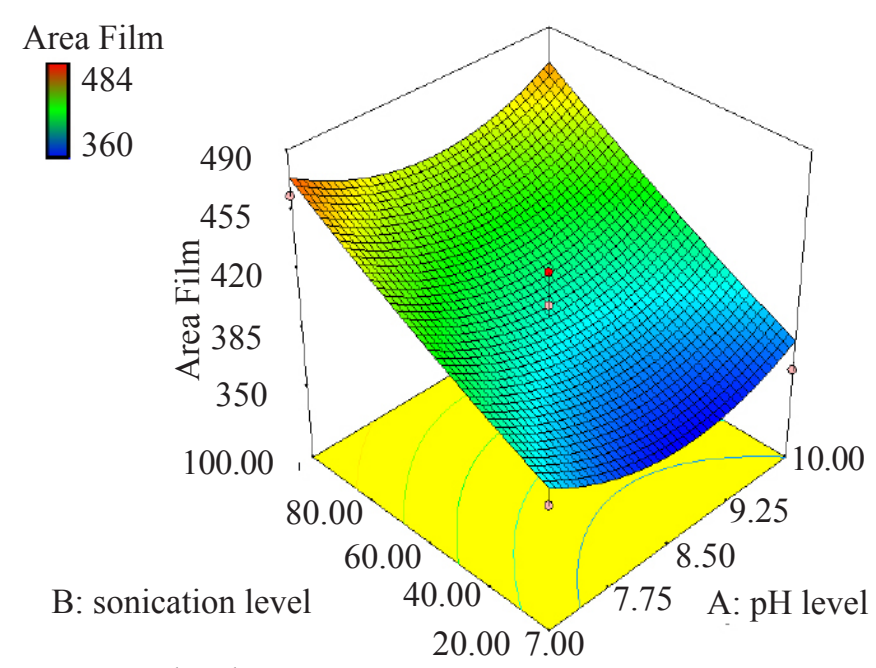

$\mathrm{X}_{1}=\mathrm{A}$ : $\mathrm{pH}$ level $\mathrm{X}_{2}=\mathrm{B}$ : sonication level

Figure 2: Response surface plot forthickness of film as $\mathrm{s}$ function of sonication levels and $\mathrm{pH}$ value

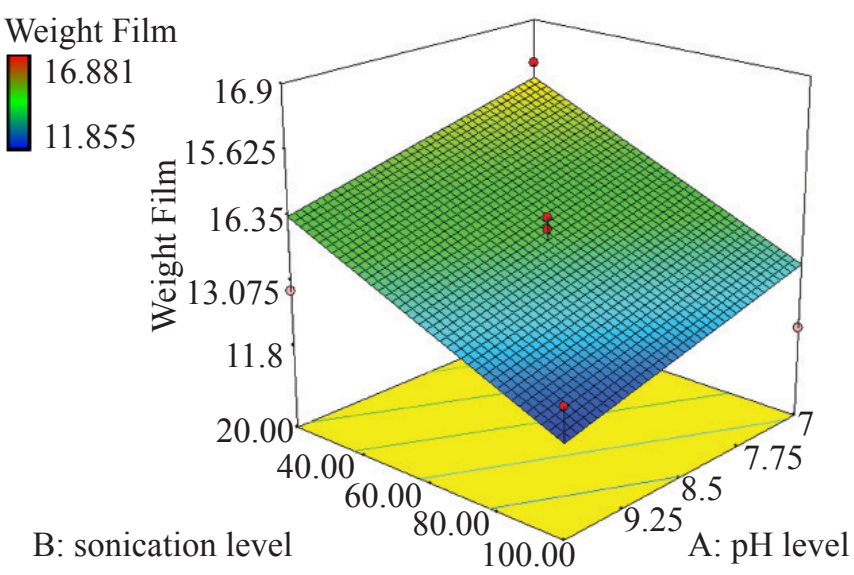
$\mathrm{X}_{1}=\mathrm{A}$ : $\mathrm{pH}$ level $\mathrm{X}_{2}=\mathrm{B}$ : sonication level

Figure 3: Response surface plot forweight of film as s function of sonication levels and $\mathrm{pH}$ value

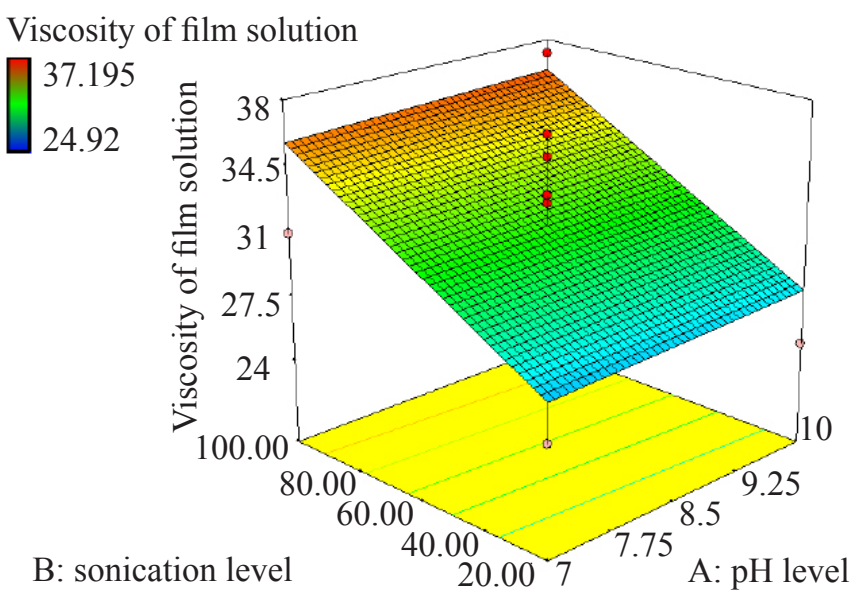
$\mathrm{X}_{1}=\mathrm{A}$ : $\mathrm{pH}$ level $\mathrm{X}_{2}=\mathrm{B}$ : sonication level Figure 4: Response surface plot forviscosity of film solution as $\mathrm{s}$ function of sonication levels and $\mathrm{pH}$ value 


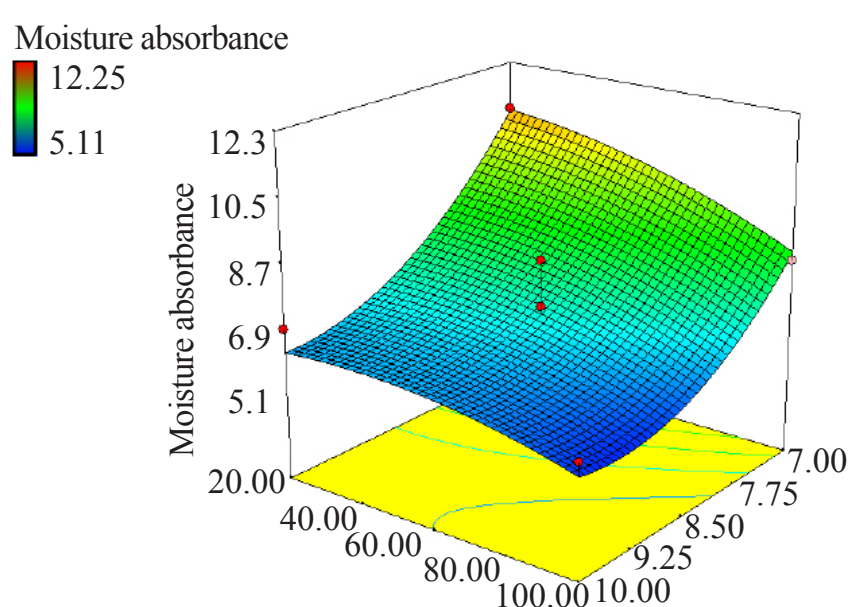

B: sonication level

A: $\mathrm{pH}$ level

$\mathrm{X}_{1}=\mathrm{A}$ : $\mathrm{pH}$ level $\quad \mathrm{X}_{2}=\mathrm{B}$ : sonication level

Figure 5: Response surface plot formoisture absorbance as $\mathrm{s}$ function of sonication levels and $\mathrm{pH}$ value

Moisture content of film
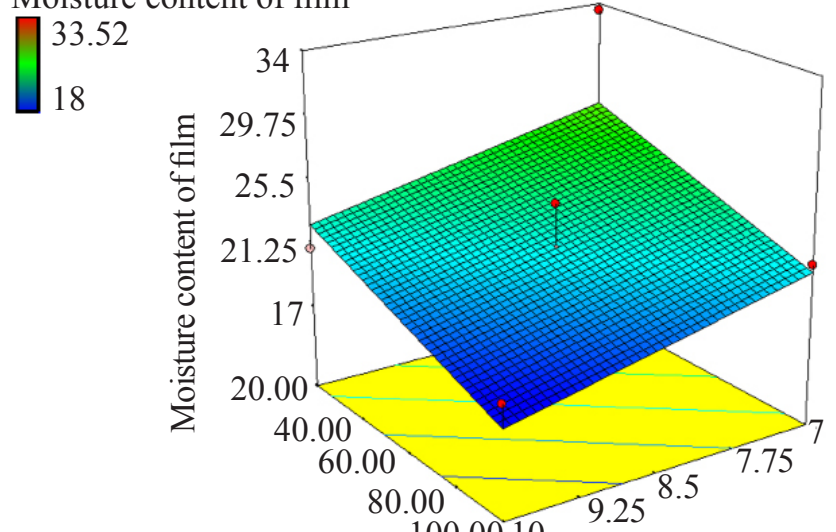

B: sonication level 100.0010

A: $\mathrm{pH}$ level

$\mathrm{X}_{1}=\mathrm{A}$ : $\mathrm{pH}$ level $\quad \mathrm{X}_{2}=\mathrm{B}$ : sonication level

Figure 6: Response surface plot formoisture content as s function of sonication levels and $\mathrm{pH}$ value

\section{Conclusion}

Effect of sonication and $\mathrm{pH}$ level of films were studied. The physical, mechanical and barrier properties, which are important in food packaging applic,ations, were examined as a function of sonication levels as well as $\mathrm{pH}$ concentrations. Sonication and $\mathrm{pH}$ led to a decrease in the MA and MC amounts of the films. Increasing sonication levels as well as $\mathrm{pH}$ level increased the films' TS and EB percent. The WVP of the films decreased by increasing, sonication treatments from 0 to $100 \%$. During study of DSC found that increasing sonication levels the melting point of film was decreased. The developed nanocomposites films can provide promising applications as effective agents in food packaging.

\section{References}

Almasi, H., Ghanbarzadeh, B., Entezami, A.A., 2010. International Journal of Biological Macromolecules $46,1-5$.

Brandenburg, A.H., Welter, C.L., Testin, R.F., 1993. Edible films and coating from soy protein. Journal of Food Science 58(5), 1086-89.

Cao, N., Fu, Y, He, J., 2007. Preparation and physical properties of soy protein isolate and gelatin composite films. Food Hydrocolloids 21, 1153-1162.

Dufresne, A., Vignon, M.R., 1998. Improvement of starch film performances using cellulose microfibrils, Macromolecules 31, 2693-2696, ISSN 0024-9297.

Dimante, L.M., Lan, T., 2014. Absolute viscosity of vegetable oils at different temperatures and shear rate range 64.5 to $4835 \mathrm{~s}^{-}{ }^{1}$. Journal of Food Processing 2014, 6 pages.

Fang, Y., Tung, M.A., Britt, I.J., Yada, S., Dalgleish, D.G., 2002. Tensile and barrierproperties of edible films made from whey proteins. Journal of Food Science 67(1), $188 \mathrm{e} 193$.

Gennadios, A., Park, H.J., Weller, C.L., 1993b. Relative humidity and temperature effects on tensile strength of edible protein and cellulose ether films. Transaction of the ASAE 36, 1867-1872.

Gennadios, A., Weller, C.L., Testin, R.F., 1993a. Modification of physical and barrier properties of edible wheat glutenbased films, Cereal Chemistry 70(4), 426-429.

Ghasemlou, M., Khodaiyan, F., Oromiehie, A., 2011. Carbohydr. Polym 84, 477-483.

Han, J., 2003. Antimicrobial food packaging. In: Ahvenainen, R. (Ed.), Novel Food Packaging CRC, Boca Raton, 50-70.

Kadam, D.M., Thunga, M., Wang, S., Kessler, M.R., Grewell, D., Lamsal, B.,Yu, C., 2013. Preparation and characterization of whey protein isolate films reinforced with porous silica coated titania nanoparticles. Journal of Food Engineering 117(1), 133-140.

Kumar, P., Sandeep, K.P., Alavi, S., Truong, V.D., Gorga, R.E., 2010. Preparation and characterization of bionanocomposite films based on soy protein isolate and montmorillonite using melt extrusion. Journal of Food Engineering 100, 480-489.

Liu, D., Chen, H., Chang, P.R., Wu, Q., Li, K., Guan, L., 2010. Biomimetic soy protein nanocomposites with calcium carbonate crystalline arrays for use as wood adhesive. Bioresource Technology 101, 6235-6241.

Liu, D., Tian, H., Kumar, R., Zhang, L., 2009. Self-assembly of nano hydroxyapatite or aragonite induced by molecular recognition to soy globulin $7 \mathrm{~S}$ or $11 \mathrm{~S}$. Macromolecular 
Rapid Communications 30, 1498-1503.

Lu,Y., Weng, L., Zhang, L., 2004. Morphology and properties of soy protein isolate thermoplastics reinforced with chitin whiskers. Biomacromolecules 5, 1046-1051.

McHugh, T.H., Krochta, J.M., 1994a. Water vapor permeability properties of edible whey protein-lipid emulsions films. Journal of the American Oil Chemist's Society 71, 307-311.

McHugh, T.H., Krochta, J.M., 1994b. Permeability properties of edible films, In: Krochta JM, Baldwin E A, NisperosCarriedo M. (Eds.), Edible coatings and films to improve food quality. Technomic Publishing Company, Lancaster, Pennsylvania, 139-188.

Mohanty, A.K., Misra, M., Drzal, L.T., 2005. Natural Fibers, Biopolymers, and Biocomposites. Taylor and Francis Group.

Monedero, F.M., Fabra, M.J., Talens, P., Chiralt, A., 2010. Effect of calcium and sodium caseinates on physical characteristics of soy protein isolate-lipid films. Journal of Food Engineering 97, 228-234.

Monedero, F.M., Fabra, M.J., Talens, P., Chiralt, A., 2009. Effect of oleic acid-beeswax mixtures on mechanical, optical and water barrier properties of soy protein isolate based films. Journal of Food Engineering 91, 509-515.

Nakayama, N., Hayashi, T., 2007. Polym. Degrad. Stab 92 1255-1264.

Park, H.M., Li, X., Jin, C.Z., Park, C.Y., Cho, W.J., Ha, C.S., 2002. Preparation and properties of biodegradable thermoplastic starch/clay hybrids. Macromolecular Materials and Engineering 287, 553-58.

Rhim, J.W., Hong, S.I., Ha, C.S., 2008. in press. Tensile, water vapor barrier and antimicrobial properties of PLA/nanoclay composite films. LWT-Food Science and Technology. doi:10.1016/j.lwt.02.015.

Rhim, J.W., Hong, S.I., Park, H.M., Ng, P.K.W., 2006. Preparation and characterization of chitosan-based nanocomposite films with antimicrobial activity. Journal of Agricultural and Food Chemistry 54, 5814-5822.

Silva, S.S., Goodfellow, B.J., Benesch, J., Rocha, J., Mano, J.F., Reis, R.L., 2007. Morphology and miscibility of chitosan/soy protein blended membranes. Carbohydrate Polymers 70, 25-31.

Sorrentino, A., Gorrasi, G., Vittoria, V., 2007. Potential perspectives of bio-nano-composites for food packaging applications Trends in Food Science \&Technology 18, 84-95.

Tang, R., Du, Y., Zheng, H., Fan, L., 2003. Preparation and characterization of soy protein isolate-carboxymethylated konjac glucomannan blend films. Journal of Applied Polymer Science 88, 1095-1099.

Tharanathan, R.N., 2003. Biodegradable films and composite coatings: past, present and future. Trends Food Sci Technol 14(3), 71-78.

Tian, H., Wang, Y., Zhang, L., Quan, C., Zhang, X., 2010a. Improved flexibility and water resistance of soy protein thermoplastics containing waterborne polyurethane. Industrial Crops and Products 32, 13-20.

Tian, H., Liu, D., Zhang, L., 2009. Structure and properties of soy protein films plasticized with hydroxylamine. Journal of Applied Polymer Science 111, 1549-1556.

Tian, H., Zhang, L., Wu, Q., Wang, X., Chen, Y., 2010 b. Creation of hydrophobic materials fabricated from soy protein and natural rubber: surface, interface, and properties. Macromolecular Materials and Engineering 295, 451-459.

Vaidya, U.R., Bhattacharya, M., 1994. Properties of blends of starch and synthetic polymers containing anhydride groups. Journal of Applied Polymer Sciences 52(5), 617-628.

Zhou, J.J., Wang, S.Y., Gunasekaran, S., 2009. Preparation and characterization of whey protein film incorporated with $\mathrm{TiO}_{2}$ nanoparticles. Journal of Food Science 74, 50-55. 